\title{
Teaching evidence-based practice on foot
}

Come along to watch some clinical teachers in action.

(1) A nurse practitioner and 2 nursing students working in a community health centre see a 51 year old woman with symptoms of menopause. The woman has had a total hysterectomy and, other than her menopausal symptoms, is healthy, with no family history of breast cancer or cardiovascular disease. She states that the symptoms are severely affecting her quality of life but seems to be reluctant to take hormone replacement therapy (HRT) because she has heard that it may affect her risk of breast cancer or heart disease. The nurse practitioner tells the woman they will do some research on the risks and benefits of HRT for her next consultation. After the consultation, she invites the students to help find and appraise evidence on this topic and "thinks aloud" about how the evidence will be used to discuss options with the woman at her next appointment.

(2) A family nurse is running a vaccination clinic with a group of nursing students. After teaching the students how to give a vaccination using a larger bore, longer needle (23 gauge, $25 \mathrm{~mm}$ ), the nurse emphasises the importance of using this type of needle because it reduces the likelihood of reactions to the vaccination. She provides the students with the reference of a study that provides evidence to support this claim.'

(3) After initiating a multilayered, high compression regimen for a patient with a venous ulcer, a specialist nurse discusses the results of quantitative studies of the effectiveness of this intervention with a group of students. The group then explores how they can use this evidence to discuss the treatment with the patient. ${ }^{2}$

$\mathrm{T}$ hese teaching moments share 4 important features. Firstly, the teaching is actually happening, despite the barriers and disincentives that clinical teachers face. ${ }^{3}{ }^{4}$ Secondly, the teaching happens "on foot" during the course of busy clinical work, rather than in a stand alone fashion. ${ }^{5}$ Thirdly, although not exclusively so, these episodes involve meaningful teaching at "the bedside." ${ }^{16-9}$ This EBN notebook examines a fourth shared feature, the use of evidence from clinical care research. In all 3 episodes described above, nurses made conscientious, explicit, and judicious use of either the process of evidence-based learning or its yield. ${ }^{10}$ The subtle but important variations in how this was done can be described as 3 different modes of teaching evidence-based practice, which are summarised in table $1 .{ }^{11}{ }^{12}$

In the first encounter, the nurse role models evidence-based practice (mode 1 in table 1 ), combining the actual doing with the "think aloud" technique to guide the learners' attention to what is being done. By using mode 1 , we demonstrate to learners how we incorporate evidence, along with other knowledge, into clinical decisions, so that they come to see the use of evidence as part of good clinical practice. We show by example that we really do it, and we can give pointers on when, where, and how to do it, too. Given the maxim "actions speak louder than words," we can expect this first mode of teaching evidence-based practice to be very effective in and of itself, and it should reinforce what learners derive from other modes.

In the second encounter, the teacher weaves evidence in among the other facts and skills being taught (mode 2 in table 1). When we teach clinical topics with evidence in the mix, we show by example how to integrate evidence with other useful knowledge in the context of preparing to make real clinical decisions so that learners come to see using evidence as part of good clinical learning. Also, because the evidence and other knowledge can be learned together, they might be better organised in memory in the elaborated networks of knowledge so important for clinical thinking. ${ }^{13}$ By using mode 2 , we are "putting our money where our mouth is"that is, spending valuable teaching time and effort on using evidence in context, so we might expect this mode to be effective as well, although we haven't seen either mode 1 or mode 2 studied.

In the third encounter, the teacher targets specific skills within evidence-based practice about which to coach the learners (mode 3 in table 1). By using mode 3, we help learners to develop their abilities for evidence-based learning, which in turn should boost their capacity for lifelong learning and professional development. By targeting one or a few specific skills at a time, the teacher makes it possible to fit these learning moments into the schedule of busy practice, knowing that the cumulative learning from many such moments can be great. Here, we get somewhat closer to having evidence about the effectiveness of this approach. The Cochrane review of trials of teaching critical appraisal skills found some evidence of improvements in participants' knowledge. ${ }^{14}$ A recent review of trials of teaching evidence-based medicine to postgraduate doctors concluded that stand-alone teaching improved knowledge, but not skills, attitudes, or behaviour, whereas teaching that was "clinically integrated into routine practice" improved knowledge, skills, attitudes, and behaviour. ${ }^{15}$ Although none of the trials appear to have tested the teaching strategies and tactics described above for modes $1-3$, table 1 shows that these modes would qualify as "clinically integrated."

Although this EBN notebook concerns teaching "on foot," there are other promising ways to teach evidence-based practice that are "clinically integrated," even if they are not "on foot." The teaching mode structure in table 1 will be used to describe 2 examples. Firstly, in an interactive large group classroom session on how to provide advice to parents of obese children, the teacher can select evidence about successful interventions to include in the material covered. In doing so, the teacher has selected to weave the results of research evidence in with other knowledge to guide explicitly the specific decisions and actions-we recognise this as teaching in mode 2 (table 1). Secondly, in a unit-wide, daily 
Table 13 modes for teaching evidence-based practice on foot

\begin{tabular}{|c|c|c|c|}
\hline & Mode 1 & Mode 2 & Mode 3 \\
\hline & $\begin{array}{l}\text { Role modelling evidence-based } \\
\text { practice }\end{array}$ & $\begin{array}{l}\text { Weaving evidence in with other } \\
\text { clinical teaching }\end{array}$ & $\begin{array}{l}\text { Targeting specific skills of } \\
\text { evidence-based practice }\end{array}$ \\
\hline What & $\begin{array}{l}\text { Demonstrate the use of evidence in } \\
\text { real clinical decisions }\end{array}$ & $\begin{array}{l}\text { Integrate evidence with other knowledge } \\
\text { when teaching clinical care }\end{array}$ & $\begin{array}{l}\text { Identify specific skills for evidence-based } \\
\text { practice to teach }\end{array}$ \\
\hline Why & $\begin{array}{l}\text { Learners see the use of evidence as } \\
\text { part of good clinical practice } \\
\text { Teach by example } \\
\text { "Actions speak louder than words" }\end{array}$ & $\begin{array}{l}\text { Learners see the use of evidence as part } \\
\text { of good clinical learning } \\
\text { Teach by explicit guiding on what to know }\end{array}$ & $\begin{array}{l}\text { Learners develop their abilities to access, } \\
\text { understand, and use evidence } \\
\text { Teach by explicit coaching on skills for } \\
\text { practice }\end{array}$ \\
\hline How & $\begin{array}{l}\text { "Think aloud" tactic } \\
\text { Demonstrate use of evidence resources } \\
\text { Debrief later to reflect on lessons }\end{array}$ & $\begin{array}{l}\text { Select one or a few of the strongest or } \\
\text { most relevant bits of evidence } \\
\text { Show how evidence fits with other } \\
\text { knowledge for action }\end{array}$ & $\begin{array}{l}\text { Select one skill area and one task within } \\
\text { that area } \\
\text { Coach learners on pragmatic specifics of } \\
\text { that skill in use }\end{array}$ \\
\hline Where & Practice settings & $\begin{array}{l}\text { Practice settings } \\
\text { Can be done in classroom, too }\end{array}$ & $\begin{array}{l}\text { Practice settings } \\
\text { Can be done in classroom, too }\end{array}$ \\
\hline When & $\begin{array}{l}\text { Little or no extra time is needed } \\
\text { Can be done almost anytime }\end{array}$ & $\begin{array}{l}\text { May add only } 1-3 \text { minutes to teaching } \\
\text { Can be done almost anytime }\end{array}$ & $\begin{array}{l}\text { May add } 2-5 \text { minutes to teaching } \\
\text { Can be done almost anytime }\end{array}$ \\
\hline Who & Any teacher, any learner & Any teacher, any learner & Teachers who can coach these skills \\
\hline
\end{tabular}

meeting such as "morning report," nursing students could be asked to bring back to the group the evidence-based answers to questions that have arisen in the care of their patients, using an educational prescription. ${ }^{16}$ In addition to facilitating the nurses' discussions of their questions, searches, appraisals, and answers, the teacher can also interject relevant and narrowly focused "slices" about the process of evidencebased practice. ${ }^{17}$ Because the teacher is targeting specific skills around which to coach learners, this is teaching in mode 3 (table 1). Most of the clinically integrated forms of teaching we've seen or read about emphasise one or more of these modes.

Keep in mind that the 3 modes in table 1 are not meant to be jointly exhaustive (ie, there are other ways to teach the wise use of evidence) or mutually exclusive (ie, hybrids do exist). Furthermore, these modes are complementary, and the best teachers of evidence-based practice we've seen use all 3, moving from one to the next to fit the clinical and teaching situation. If we actually use evidence in our own practice and clinical teaching (modes 1 and 2), we will have more realism and legitimacy when we coach our learners on specific skills of evidence-based practice (mode 3 ).

What can we do to prepare to teach in these 3 modes? The following 7 suggestions can help us prepare for any mode. Firstly, we should refine our own skills in evidence-based practice so that we are sufficiently competent to serve as role models. Secondly, we can work to gain access to needed evidence resources, whether through our healthcare system (local or national) or on our own. Thirdly, because we encounter some problems and decisions repeatedly, we can anticipate the questions we will have and track down evidence-based answers ahead of time, so that they are ready for use when the time comes. Fourthly, rather than store the entire text of the evidence, we might assemble and keep available concise summaries of the evidence, such as the one page summaries from evidence-based synoptic journals such as Evidence-Based Nursing or from our own CATs (critically appraised topics) ${ }^{18}$ or eCAT's. ${ }^{19}$ Fifthly, for some of these recurring decisions, investigative teams have assembled evidence-based decision aids to explicitly guide our patients and ourselves through the process of integrating evidence with values. We can retrieve these ahead of time and keep them within reach. ${ }^{20}$ Sixthly, it can be useful to obtain and keep handy some "how to" references on evidence-based practice that are appropriate to our discipline. $^{12}{ }^{21}$ Seventhly, we should develop our teaching awareness, or reflection-in-action, that allows us to recognise the teaching moments as they occur and helps us choose which to let pass and which to seize upon. ${ }^{22}$

Beyond these 7 suggestions, a few things can be done ahead of time to prepare to teach in each mode. For mode 1 , role modelling, many of us feel more comfortable being observed by learners using evidence in real patient care after practising its use several times without a watching learner. Once we feel comfortable with when, how, and how much evidence to add to our patient encounters, we will be better able to demonstrate to others this "flavouring" or "spice" in our practice. For mode 2, we can anticipate that certain bits of evidence will be used alongside predictable aliquots of other knowledge, and we can prepare these mixtures ahead of time, as "teaching vinaigrettes." ${ }^{23}$ For mode 3, it can help to prepare some short (2-5 min) scripts about the specific skills you will be targeting, as "teaching slices" of evidence-based practice (rather than the whole pie), ${ }^{17}$ whether your own or from others. ${ }^{24-27}$

How can we improve further our teaching of evidencebased practice? As a complex craft built on experience as well as knowledge, excellence in teaching takes time to develop. Table 2 includes 5 suggestions for using that time well. Firstly, to develop excellence or even mastery, we probably need to undertake deliberate practice, where we purposefully and repeatedly engage in activities designed to improve aspects of our craft. ${ }^{28}{ }^{29}$ Secondly, we can keep reflective teaching journals to record observations and interpretations of our own teaching, including both successes and failures, ${ }^{30} 31$ as well as observations of other teachers, including those outside nursing. ${ }^{32}$ Thirdly, we can identify respected teachers at our own institutions who can observe our teaching and provide us with detailed feedback and coaching. ${ }^{33}$ Fourthly, we can attend one of the growing number of workshops on teaching evidence-based practice being held around the world. ${ }^{34}$ Fifthly, because teaching is so intertwined with learning, we can learn 
Table 2 Learning more about teaching evidence-based practice

\begin{tabular}{|c|c|c|}
\hline Strategy or tactic & Why? & How? \\
\hline Deliberate practice of teaching ${ }^{2829}$ & $\begin{array}{l}\text { Purposeful refinement of teaching craft } \\
\text { "Practice makes perfect" }\end{array}$ & $\begin{array}{l}\text { Select areas on which to focus attention } \\
\text { Identify new or alternate strategy or tactic to try out (eg, } \\
\text { from the Teaching Tips series }{ }^{24-27} \text { ) } \\
\text { Practice new strategy or tactic repeatedly, reflecting } \\
\text { after each use on what worked well and what could be } \\
\text { improved }\end{array}$ \\
\hline Keep a teaching journal & $\begin{array}{l}\text { Record observations and interpretations of teaching } \\
\text { and learning experiences } \\
\text { Boosts reflective practice }\end{array}$ & $\begin{array}{l}\text { Take prospective notes on planning, execution, and } \\
\text { reflection of one's teaching } \\
\text { Add observations from others' teaching } \\
\text { Add insights from reading about learning and teaching }\end{array}$ \\
\hline Get coached on teaching & Learn more about teaching from peers and masters & $\begin{array}{l}\text { Identify skilled teachers who are able and willing to be } \\
\text { a teaching coach } \\
\text { Do real teaching while coach observes } \\
\text { Debrief afterward to reflect on the lessons }\end{array}$ \\
\hline $\begin{array}{l}\text { Attend courses on teaching evidence-based } \\
\text { practice }\end{array}$ & $\begin{array}{l}\text { Concentrated focus on building teaching skills and } \\
\text { repertoire during short period of time } \\
\text { Learn through sharing teaching craft with others }\end{array}$ & $\begin{array}{l}\text { Find and attend a course that best fits your learning and } \\
\text { teaching needs }{ }^{34}\end{array}$ \\
\hline Learn more about human learning & $\begin{array}{l}\text { Helps build conceptual models that underlie our } \\
\text { teaching craft } \\
\text { Boosts range of teaching options available } \\
\text { Helps troubleshooting when teaching goes awry }\end{array}$ & $\begin{array}{l}\text { Find and use resources on } \\
\text { (a) human learning in general }{ }^{35-41} \\
\text { (b) learning in specific settings, such as in small } \\
\text { groups }{ }^{42-48}\end{array}$ \\
\hline
\end{tabular}

more about how humans learn and how this learning can be facilitated. ${ }^{35-48}$

This EBN notebook has focused on how to teach evidencebased practice as part of clinical teaching, not on whether to do so. ${ }^{49}$ We have tried to collect here the teaching strategies and tactics that we, and others, have found useful, and we look forward to learning more from many of you.

W SCOTT RICHARDSON, MD Dept of Internal Medicine, Wright State University School of Medicine and Three Owl Learning Institute Dayton, Ohio, USA

DAWN DOWDING RN, PhD Department of Health Sciences, University of York and Hull York Medical School

York, UK

A modified version of this notebook appears in ACP Journal Club and Evidence-Based Medicine.

1 Diggle L, Deeks J. Effect of needle length on incidence of local reactions to routine immunisation in infants aged 4 months: randomised controlled trial. BMJ 2000;321:931-3.

2 Cullum N, Nelson EA, Fletcher AW, et al. Compression for venous leg ulcers. Cochrane Database Syst Rev 2001;(2):CD000265.

3 DeAngelis CD. Professors not professing. JAMA 2004;292:1060-1.

4 LaCombe M. High society. CMAJ 2002;166:1044-5.

5 Hurst JW. The overlecturing and underteaching of clinical medicine. Arch Intern Med 2004; 164:1605-8.

6 Morgan WL Jr. Bedside teaching. Trans Am Clin Climatol Assoc $1981 ; 93: 164-71$

7 Fitzgerald FT. Bedside teaching. West J Med 1993;158:418-20.

8 Kroenke K, Omori DM, Landry FJ, et al. Bedside teaching. South Med J 1997:90:1069-74.

9 LaCombe MA. On bedside teaching. Ann Intern Med 1997;126:217-20

10 Sackett DL, Rosenberg WM, Gray JA, et al. Evidence based medicine: what it is and what it isn't. BMJ 1996;312:71-2.

11 Richardson WS. One, two, three ... teach! Evidence-Based Health Care Newsletter 1999:19:6-7.

12 Straus SE, Richardson WS, Glasziou P, et al. Evidence-based medicine: how to practice and teach EBM. Third edition. New York: Elsevier/Churchill Livingstone, 2005.

13 Bordage $G$. Elaborated knowledge: a key to successful diagnostic thinking. Acad Med 1994;69:883-5.

14 Parkes J, Hyde C, Deeks J, et al. Teaching critical appraisal skills in health care settings. Cochrane Database Syst Rev 2001 ;(3):CD001270.

15 Coomarasamy A, Khan KS. What is the evidence that postgraduate teaching in evidence based medicine changes anything? A systematic review. BMJ 2004;329:1017.
16 Richardson WS. Teaching evidence-based medicine in morning report. Clinical Epidemiology Newsletter 1993;13:9

17 Richardson WS. One slice or the whole pie? Evidence-Based Health Care Newsletter 2001;21:17-18.

18 Sauve S, Lee HN, Meade MO, et al. The critically appraised topic: a practical approach to learning critical appraisal. Ann R Coll Physicians Surg Can 1995;28:396-8.

19 Richardson WS, Burdette SD. Practice corner: taking evidence in hand. ACP J Club 2003:138:A9.

$20 \mathrm{O}^{\prime}$ Connor AM, Légaré F, Stacey D. Risk communication in practice: the contribution of decision aids. BMJ 2003;327:736-40.

21 DiCenso A, Guyatt GH, Ciliska D, editors. Evidence-based nursing: a guide to clinical practice. St Lovis, MO: Elsevier Mosby, 2005.

22 Branch WT Jr, Paranjape A. Feedback and reflection: teaching methods for clinical settings. Acad Med 2002;77:1 185-8.

23 Richardson WS. Teaching vinaigrettes for evidence-based practice. EvidenceBased Health Care Newsletter 2004:24:11.

24 Wyer PC, Keitz S, Hatala R, et al. Tips for learning and teaching evidencebased medicine: introduction to the series. CMAJ 2004;171:347-8.

25 Barratt A, Wyer PC, Hatala R, et al. Tips for learners of evidence-based medicine: 1. Relative risk reduction, absolute risk reduction and number needed to treat. CMAJ 2004;171:353-8.

26 Montori VM, Kleinbart J, Newman TB, et al. Tips for learners of evidencebased medicine: 2. Measures of precision (confidence intervals). CMAJ 2004:171:611-5.

27 McGinn T, Wyer PC, Newman TB, et al. Tips for learners of evidence-based medicine: 3 . Measures of observer variability (kappa statistic). CMAJ 2004;171:1369-73

28 Ericsson KA. Deliberate practice and the acquisition and maintenance of expert performance in medicine and related domains. Acad Med 2004;79:S70-81.

29 Ericsson KA, editor. The road to excellence: the acquisition of expert performance in the arts and sciences, sports, and games. Mahwah, NJ: Lawrence Erlbaum, 1996.

30 Pinsky LE, Monson D, Irby DM. How excellent teachers are made: reflecting on success to improve teaching. Adv Health Sci Educ Theory Pract 1998;3:207-15.

31 Pinsky LE, Irby DM. "If at first you don't succeed:" using failure to improve teaching. Acad Med 1997;72:973-6.

32 Conn JJ. What can clinical teachers learn from Harry Potter and the Philosopher's Stone? Med Educ 2002;36:1 176-81.

33 Beckman TJ. Lessons learned from a peer review of bedside teaching. Acad Med 2004;79:343-6.

34 Richardson WS. A teacher's dozen. Nordic Evidence-Based Health Care Newsletter 2001:5:16-17.

35 Schön DA. Educating the reflective practitioner: toward a new design for teaching and learning in the professions. San Francisco, CA: Jossey-Bass, 1987.

36 Candy PC. Self-direction for lifelong learning: a comprehensive guide to theory and practice. San Francisco, CA: Jossey-Bass, 1991. 
37 Neighbour R. The inner apprentice: an awareness-centred approach to vocational training for general practice. Newbury, UK: Petroc Press, 1996

38 Palmer PJ. The courage to teach: exploring the inner landscape of a teacher's life. San Francisco, CA: Jossey-Bass, 1997

39 Claxton G. Wise-up: the challenge of lifelong learning. New York, NY: Bloomsbury, 1999.

40 Bransford JD, Brown AL, Cocking RR, editors. How people learn: brain, mind, experience, and school. Washington, DC: National Academy Press, 1999.

41 Brown JS, Duguid P. The social life of information. Boston, MA: Harvard Business School Press, 2000

42 Tiberius RG. Small group teaching: a troubleshooting guide. Toronto, Ontario: OISE Press, 1989.
43 Westberg J, Jason H. Fostering learning in small groups: a practical guide. New York: Springer Publishing Company, 1996.

44 Brookfield SD, Preskill S. Discussion as a way of teaching: tools and techniques for democratic classrooms. San Francisco, CA: Jossey-Bass, 1999.

45 Maudsley $G$. Roles and responsibilities of the problem based learning tutor in the undergraduate medical curriculum. BMJ 1999;318:657-61.

46 Jaques D. Learning in groups: a handbook for improving group working Third edition. London: Kogan Page, 2000.

47 Wood DF. Problem based learning. BMJ 2003;326:328-30.

48 Jaques D. Teaching small groups. BMJ 2003;326:492-4

49 Whitcomb ME. Why we must teach evidence-based medicine. Acad Med 2005;80:1-2.

\section{Letter}

$\mathrm{T}$ he commentary by Griffiths regarding the Cochrane review on the effectiveness of hip protectors for reducing hip fractures published in the January 2005 issue of Evidence-Based Nursing ${ }^{1}$ highlights important methodological considerations that may account for the failure of this review to demonstrate a reduction in fractures among elderly people living in residential care. Although we concur with Griffiths' conclusion that it is premature to advise patients to stop using hip protectors, we would like to advance 3 other important considerations.

Firstly, falls among older adults are often multifactorial, and therefore, prevention requires a multiple intervention approach. ${ }^{2}$ That is, multiple strategy interventions that target risk factors for falls at individual, health provider, and organisational levels should be offered. If hip protectors are offered as part of a multiple intervention programme for falls prevention, elderly people may be reminded that hip protectors alone do not prevent falls and perhaps dissuaded from developing a false sense of confidence when wearing hip protectors and taking undue risks. Secondly, a review of the studies included in the Cochrane review by Parker et al indicated that many of the staff training interventions described were brief and not informed by appropriate theory. The study by Meyer et $a l^{3}$ was an exception. These authors described a theory based, multilevel intervention. Their tailored education sessions to promote the use of hip protectors by staff illustrates the intense training that may be required to effect a change in staff behaviour and subsequently, patient use of hip protectors. Finally, when clinicians advise elderly people to use hip protectors, they need to be cognisant of several issues: hip protectors with an energy shunting mechanism provide the most protection; ${ }^{4}$ hip protectors must be worn correctly in order to provide protection from hip fractures; and reinforcing messages are needed to encourage their continued use. The review by Parker et al and the commentary by Griffiths remind us that introducing a new innovation into clinical practice is a complex undertaking that must be supported by well designed multiple intervention programmes.

\section{NANCY EDWARDS, RN, PhD School of Nursing and Department of Epidemiology and Community Medicine University of Ottawa}

KOREEN E FAHEY, RN, MN Élisabeth Bruyère Research Institute Ottawa, Ontario, Canada

1 Griffiths P. Commentary on "Review: evidence from individually randomized trials shows that hip protectors do not reduce hip fractures in elderly people. Evidence Based Nursing 2005;8:24. Comment on: Parker MJ, Gillespie LD, Gillespie WJ. Hip protectors for preventing hip fractures in the elderly. Cochrane Database Syst Rev 2004;(3):CD001 255

2 Edwards N, Mill J, Kothari AR. Multiple intervention research programs in community health. Can J Nurs Res 2004;36:40-54.

3 Meyer $G$, Warnke A, Bender R, et al. Effect on hip fractures of increased use of hip protectors in nursing homes: cluster randomised controlled trial. BMJ 2003;326:76.

4 Sveistrup $\mathrm{H}$, Lockett D. Hip protectors and community-living seniors: a review of the literature, Monograph No M04-04. Ottawa: University of Ottawa, Community Health Research Unit, 2004.

\section{Commentator response}

W hen reviewing evidence, it is crucial to remember the maxim that absence of evidence of effect is not the same as evidence of no effect. Those who criticise evidence-based practice often remind us of the need to examine evidence in the round and not take too narrow a focus. These are important reminders. This wider view and considered judgment is reflected in the fact that neither the review by Parker et al, ${ }^{1}$ nor my commentary, ${ }^{2}$ simply dismissed the use of hip protectors based on an overall lack of evidence of benefit.

However, absence of evidence is absence of evidence. The important methodological consideration I noted, which is highlighted by Edwards and Fahey, is that in institutional settings, any benefit of hip protectors might be masked by contamination of any control group in individually randomised controlled trials. Thus, there is no a priori reason for setting the results of individually randomised controlled trials above cluster randomised controlled trials. Hence the conclusion, despite the absence of evidence in individual randomised trials, that "data from cluster randomised studies provide some evidence of effectiveness of hip protectors in reducing the risk of hip fractures in those living in nursing homes and considered to be a high risk of hip fractures". ${ }^{1}$

This consideration does not apply in community settings, where the opportunity for contamination of the intervention is low. So when Edwards and Fahey suggest that "...if hip protectors are offered as part of a multiple intervention programme for falls prevention, elderly people may be reminded that hip 
104

protectors alone do not prevent falls and perhaps dissuaded from developing a false sense of confidence when wearing hip protectors and taking undue risks..." they might well be correct. They are free to speculate, and the mechanism seems at least plausible. But there is no evidence to support this assertion for community dwelling older people because there is no evidence of benefit. Furthermore, there is no evidence to support this as a mechanism for any benefit among those in institutions to whom (I speculate) it is least likely to apply. Specifically there is no overall evidence that the incidence of falls is reduced. ${ }^{1}$

The study by Meyer et $a l^{3}$ is singled out by Edwards and Fahey because of the way the intervention was delivered. In particular, they draw attention to the fact that there was a description of tailored educational support for nurses in the intervention sites. But use of protectors in this study, at 34\%, was lower than in many of the studies reported by Parker et al. Even when considering the least generous estimate of compliance from other studies, this falls below the median. However, it should be noted that in the study by Meyer et al, a higher proportion of people who fell were users of protectors. Even so, only $58 \%$ of falls occurred when a protector was worn. Even after intensive training of staff, a significant level of non-compliance remains.

This brings me to the final point made by Edwards and Fahey. They state that when advising elderly people, clinicians must remember that ".... hip protectors must be worn correctly in order to provide protection from hip fractures..." and "hip protectors with an energy shunting mechanism provide the most protection..." Perhaps this is a reasonable "best bet" when advising those who choose to use them. However, clinicians must also bear in mind that the evidence of benefit is limited to laboratory and institutional settings and that there is considerable evidence that current devices are simply not acceptable to many clients.

Evidence-based health care has been accused in the past of ignoring patient preference in the face of evidence of effectiveness from trials. Surely then, it is hard to condone ignoring preference in the absence of such evidence? Thus, I would like to reiterate my main conclusion about hip protectors. There seems little evidence to justify their use outside of properly designed research programmes. Practitioners would do better to concentrate their efforts on implementing interventions known to prevent falls.

PETER GRIFFITHS, RN, PhD King's College, University of London London, UK

1 Parker MJ, Gillespie LD, Gillespie WJ. Hip protectors for preventing hip fractures in the elderly. Cochrane Database Syst Rev 2004;(3):CD001255.

2 Griffiths P. Commentary on "Review: evidence from individually randomized trials shows that hip protectors do not reduce hip fractures in elderly people. Evidence Based Nursing 2005;8:24. Comment on: Parker MJ, Gillespie LD, Gillespie WJ. Hip protectors for preventing hip fractures in the elderly. Cochrane Database Syst Rev 2004:(3):CD001255.

3 Meyer G, Warnke A, Bender R, et al. Effect on hip fractures of increased use of hip protectors in nursing homes: cluster randomised controlled trial. BMJ 2003;326:76.

\section{How to cite material from Evidence-Based Nursing \\ Citation of material from an editorial}

Mullhall A. Nursing, research, and evidence [editorial]. Evidence-Based Nursing 1998;1:4-6.

Citation for material taken from a structured abstract, written without attribution by a staff member Sucrose and commercially available milk reduced crying in newborns, during a blood collection procedure [abstract]. Evidence-Based Nursing 1998;1:10. Abstract of: Blass EM. Milk-induced hypoalgesia in human newborns. Pediatrics 1997;99:825-9.

Citation for material taken from a commentary to an article

Carlisle C. Commentary on "A conceptual model described how adults responded to a simulated literacy assessment." Evidence-Based Nursing 1998;1:29. Comment on: Brez SM, Taylor M. Assessing literacy for patient teaching: perspectives of adults with low literacy skills. J Adv Nurs 1997;25:1040-7. 